\title{
Spontaneous activity in the developing retina emerges at a critical state between local and global functional connectivity Matthias H Hennig*1, Christopher Adams ${ }^{2}$, David Willshaw ${ }^{1}$ and Evelyne Sernagor ${ }^{2}$
}

\author{
Address: ${ }^{1}$ ANC, School of Informatics, University of Edinburgh, Edinburgh, UK and ${ }^{2}$ Institute of Neuroscience, Medical Sciences, University of \\ Newcastle upon Tyne, Newcastle upon Tyne, UK \\ Email: Matthias H Hennig* - m.hennig@ed.ac.uk \\ * Corresponding author
}

from Eighteenth Annual Computational Neuroscience Meeting: CNS*2009

Berlin, Germany. 18-23 July 2009

Published: 13 July 2009

BMC Neuroscience 2009, 10(Suppl I):P67 doi:10.1 I86/I47I-2202-I0-SI-P67

This abstract is available from: http://www.biomedcentral.com/I47I-2202//0/SI/P67

(C) 2009 Hennig et al; licensee BioMed Central Ltd.

Patterned, spontaneous neural activity is observed in many parts of the developing nervous system, and is known to play an important role in its development and maturation [1]. It is still unclear whether simply the presence of a certain level of neural activity is sufficient for normal development, or whether specific spatio-temporal features of the activity are also relevant. To address this question, we use computational modeling and multielectrode array recordings to investigate in detail the properties of retinal waves. Retinal waves are spontaneous, propagating activity patterns found in the immature retina of many vertebrate species [2,3], which display highly random initiation points, sizes and trajectories [4]. Here we propose a biophysically realistic model for early-stage, acetylcholine-mediated retinal waves, which reproduces these properties and offers a simple explanation in terms of a model from statistical mechanics. In this model, neurons in a recurrently connected network produce spontaneous bursts, which can trigger propagating waves when neighbouring neurons are sufficiently excitable. Neural excitability is regulated through a slow after-hyperpolarization (sAHP) current operating on two different temporal scales [5]. As a result, the network exhibits competition between a desynchronizing effect of spontaneous, cellintrinsic bursts, and the synchronizing effect of synaptic transmission during propagating retinal waves. Cellintrinsic bursts decouple the retinal network through acti- vation of the sAHP current, and we show that the network is capable of operating at a transition point between purely local and global functional connectedness. Comparison with a simple mean-field model shows that this corresponds to a percolation phase transition. Analysis of multielectrode array recordings of retinal waves in turtles and mice confirms that, at this point, their properties, in particular. the scale free nature of the activity patterns are reliably predicted by the model. These results indicate that early-stage retinal waves are regulated according to a very specific principle, which maximizes randomness and variability in the resulting activity patterns. Since retinal waves are known to influence the development of both the retinal network [2] and of higher visual brain centers [6], we suggest that such activity may be required since it contains events on all length scales, and is unbiased with respect to scale or sequence of events. In addition, the scale-free character of retinal waves could present the visual system with an early opportunity to adapt to the statistics later also encountered in natural images.

\section{References}

I. Moody WJ, Bosma MM: Ion channel development, spontaneous activity, and activity-dependent development in nerve and muscle cells. Physiol Rev 2005, 85:883-94I.

2. Sernagor E, Eglen SJ, Wong ROL: Development of retinal ganglion cell structure and function. Prog Retin Eye Res 200I, 20:139-174. 
3. Wong ROL: Retinal waves and visual system development. Annul Rev Neurosci 1999, 22:29-47.

4. Feller MB, Butts DA, Aaron HL, Rokhsar DS, Shatz CJ: Dynamic processes shape spatiotemporal properties of retinal waves. Neuron 1997, 19:293-306.

5. Zheng J, Lee S, Zhou ZJ: A transient network of intrinsically bursting starburst cells underlies the generation of retinal waves. Nat Neurosci 2006, 9:363-37I.

6. Firth SI, Wang CT, Feller MB: Retinal waves: mechanisms and function in visual system development. Cell Calcium 2005, 37:425-432.

Publish with Bio Med Central and every scientist can read your work free of charge

"BioMed Central will be the most significant development for disseminating the results of biomedical research in our lifetime. "

Sir Paul Nurse, Cancer Research UK

Your research papers will be:

- available free of charge to the entire biomedical community

- peer reviewed and published immediately upon acceptance

- cited in PubMed and archived on PubMed Central

- yours - you keep the copyright

Submit your manuscript here:

http://www.biomedcentral.com/info/publishing_adv.asp 